\title{
19. ORGANIC DEPOSITION AT A CONTINENTAL RISE: ORGANIC GEOCHEMICAL INTERPRETATION AND SYNTHESIS AT DSDP SITE 397, EASTERN NORTH ATLANTIC
}

\author{
Chris Cornford, Programmgruppe fur Erdoel und Organische Geochemie der Kernforschungsanlage Jülich \\ GMBH, D-517 Julich, West Germany ${ }^{1}$
}

\begin{abstract}
The deposition of organic matter in the deep oceans is discussed and it is noted that, while particulate matter in deep sea water contains 20 to 50 per cent organic carbon, the accumulated sediment typically contains 0.3 per cent organic carbon. Differential settling is discussed and quantified. It is concluded that benthic activity reduces organic carbon concentration by one order of magnitude at or immediately below the sea floor. The organic geochemical reports on DSDP Site 397 are reviewed and the results related to the broader geological setting of the site. It is concluded that the relatively high geothermal gradient and organic maturity in the sediments studied is related to high heat flow of the nearby Canary Islands volcanic center. On the basis of the predominance of higher plant (terrestrial) kerogen at this continental rise site, a model for the preferential survival of the land-derived organic matter is proposed: planktonic matter produced by high bioproductivity in the upwelling waters of the Tertiary is poorly preserved. Slumping and turbidity flow are shown to be mechanisms for the emplacement into the deep-water rise setting of organic-rich sediments, originally deposited under oxygen-minimum conditions on the shelf edge.
\end{abstract}

\section{INTRODUCTION}

That part of the carbon cycle operating in deep ocean waters and associated sediments, past and present, is poorly understood. Some understanding is necessary if the organic matter of deep-sea sediments is to be related via transport and depositional mechanisms to its source on land or in the sea. For example, the extent of biodegradation or reworking of organic matter by bottom fauna (benthics) and bacteria within the sediments of deep ocean basins is a point of discussion, but it will determine the extent of preservation of easily bio-degradable organic matter. Also poorly understood is the extent of seaward transport of terrestrial organic matter. To answer these and other questions, a carbon mass balance is attempted in this report.

The majority of the organic geochemical reports on DSDP Site 397 concern only the hydrocarbon source rock characteristics and maturity. This report discusses the conclusions of the organic geochemical reports, and attempts to relate these findings to the detailed stratigraphic, sedimentological, and regional data available for this site. Of the Site 397 organic geochemical investigators, Deroo et al. and Cornford et al. (this volume) took individual samples. The remainder of the investigators took portions of the $50-\mathrm{cm}$ core lengths collected

\footnotetext{
${ }^{1}$ Present address: The British National Oil Corp., 150 St. Vincent St., Glascow G2 5LJ, United Kingdom.
}

for the Organic Geochemistry Panel. The results from any one set of subsamples therefore, should, be directly comparable within the limits of sediment homogeneity.

The reports of Whelan (this volume) concerning gaseous hydrocarbons, and Baker and Palmer (this volume) concerning porphyrin pigments, emphasize different aspects of organic geochemistry and are not considered in this synthesis. Insufficient background is currently available to interpret the data in a more general way.

\section{ORGANIC DEPOSITION IN THE DEEP OCEAN}

Relating the types of organic matter found in deep ocean sediments to their sources implies a knowledge of transport and depositional mechanisms. At present, this knowledge is in a state of qualitative speculation (Hunt, 1974; Gormley and Sackett, 1977). McCave (1975) discussed the vertical flux of particles in the ocean, while Meinhold (1977) quantitatively treated the cycling of organic matter in the world's oceans.

Possible mechanisms for the transport of organic matter are represented in Figure 1. These are eolian transport followed by settling through the water body (Milliman, 1977; Simoneit and Eglinton, 1977); from the autochthonous biomass (zooplankton and phytoplankton) produced in near-surface waters, followed by settling (Menzel, 1974); from allochthonous suspended organic particles introduced by rivers from a terrestrial source (e.g., Gardner and Menzel, 1974; Gadel and Ragot, 1974); by turbidity current flow or 


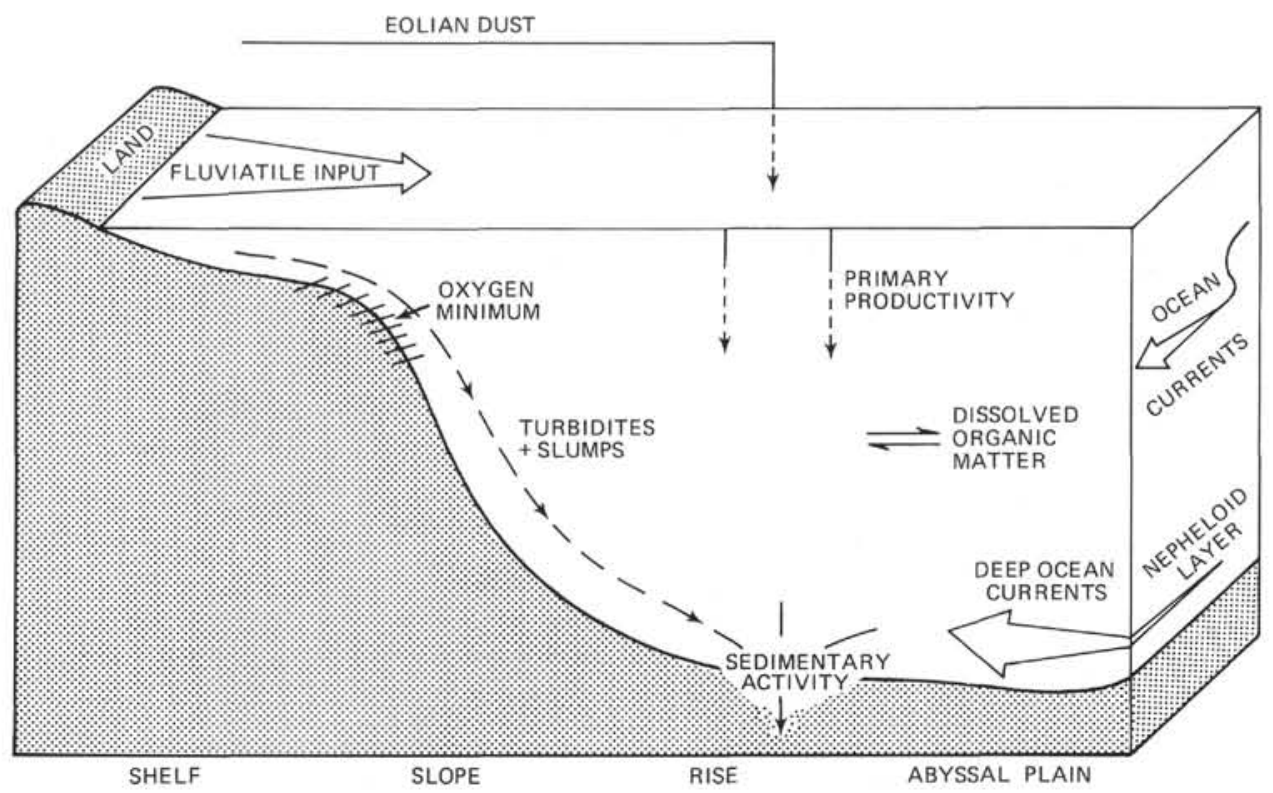

Figure 1. Factors effecting the organic matter content of deep-sea sediments.

slumping (Site Chapter, this volume; Jacobi, 1976); and settling from suspension in ocean currents, or by settling from the nepheloid layer produced by deep water bottom currents (Biscaye and Eittreim, 1977). Exchange between dissolved and particulate organic carbon is also a possiblity (Gormly and Sackett, 1977).

Some extreme cases of accumulation of organic-rich sediments under oxygen deficient conditions have been discussed in the literature (Richards, 1970; Schlanger and Jenkins, 1976; Ryan and Cita, 1977) but few discussions are found of the general case (Gormly and Sackett, 1977).

Near-surface waters (e.g., 0 to $400 \mathrm{~m}$ ) of open oceans contain 25 to $750 \mu \mathrm{g} / 1$ of suspended particulate matter, which includes 30 to $300 \mu \mathrm{g} / 1$ of particulate organic carbon (Table 1). Below about 400 meters, the total suspended particulate matter falls in the range 25 to $100 \mu \mathrm{g} / 1$, and may show some lateral and vertical anomalies (Brewer et al., 1976). A minimum ("the clear water minimum") has been described between 2000 and 4000 meters in the Atlantic (Biscaye and Eittreim, 1977). Near the sea floor, the nepheloid layer occurs (McMaster et al., 1977) which can contain up to one order of magnitude more suspended particulate matter (Table 1).

Particulate organic matter below about 400 meters is found at a relatively constant concentration in the range 5 to $75 \mu \mathrm{g} / 1$ (Table 1); a value of $10 \mu \mathrm{g} / 1 \mathrm{can}$ be taken as typical (Menzel, 1974). It has also been noted that the particulate organic matter at depth is independent of the surface bioproductivity (Menzel, 1974), most carbon being recycled in the upper water column. The opposite appears true for total particulate concentrations (Biscaye and Eittreim, 1977). The majority of organic carbon that sinks below this upper layer is contained in fecal pellets. As shown in Table 1, the waters of the Cariaco Trench contain anomalously high particulate organic matter concentrations at depth,
TABLE 1

Total Particulate Matter and Particulate Organic Carbon Variation With Depth: A Compilation of Literature Data (bracketed values $=$ ranges; unbracketed $=$ means)

\begin{tabular}{|c|c|c|}
\hline & $\begin{array}{c}\text { Particulate } \\
\text { Organic Carbon }(\mu \mathrm{g} / \mathrm{l})\end{array}$ & $\begin{array}{l}\text { Total Particulate } \\
\text { Matter }(\mu \mathrm{g} / \mathrm{l})\end{array}$ \\
\hline $\begin{array}{l}\text { Surface waters } \\
(0 \text { to } 400 \mathrm{~m})\end{array}$ & $\begin{array}{l}30(15-52)^{\mathrm{d}} 50^{\mathrm{h}} 0.5 \\
(140-420)^{\mathrm{e}} 12(05-145)^{\mathrm{j}} \\
(100-300)^{\mathrm{g}}(100-250)^{\mathrm{k}}\end{array}$ & $\begin{array}{l}20-80^{\mathrm{a}} \\
140(16-670)^{\mathrm{d}} \\
(250-750)^{\mathrm{e}}\end{array}$ \\
\hline $\begin{array}{l}\text { Middle and deep waters } \\
(>400 \mathrm{~m} \text { from surface to } \\
>1000 \mathrm{~m} \text { from sea floor })\end{array}$ & $\begin{array}{l}5-10^{\mathrm{b}} 4(0.5-33)^{\mathrm{j}} \\
10(3-10)^{\mathrm{f}}(20)^{\mathrm{k}} \\
60(50-75)^{\mathrm{h}}(16-50)^{1}\end{array}$ & $\begin{array}{l}20(12-25)^{\mathrm{a}} \\
3.5^{\mathrm{c}}\end{array}$ \\
\hline $\begin{array}{l}\text { Nepheloid layer } \\
\text { (<1000 } \mathrm{m} \text { from deep } \\
\text { sea floor) }\end{array}$ & $(1.6-3.0)^{\mathrm{j}}$ & $\begin{array}{l}20-200^{\mathrm{a}} \\
150^{\mathrm{c}} \\
(320)^{\mathrm{d}}\end{array}$ \\
\hline
\end{tabular}

Sediment accumulation and lithification

Deep-sea sediments

$(0.3 \% \mathrm{C}-\mathrm{org})^{\mathrm{m}}$

Sources: (a) Brewer et al., 1976 (Atlantic); (b) Menzel and Ryther, 1970 (Pacific and Atlantic); (c) Biscaye and Eittreim, 1977 (Atlantic); (d) McMaster et al., 1977 (Atlantic, W. Africa coast); (e) Milliman, 1977 (Atlantic West Africa coast); (f) Menzel, 1974 (world mean); (g) Huntsman and Barber, 1977 (Atlantic, West Africa coast); (h) Karl et al., 1977, (Cariaco Trench); (j) Gordon, 1977 (NW Atlantic); (k) Parsons and Seki, 1970; (1) Riley, 1970 (review, North Atlantic); (m) Mclver, 1975 (worldwide).

but these occur in the anoxic zone below 500 meters (Karl et al., 1977). Dissolved organic carbon in deep sea water is typically between 350 and $700 \mu \mathrm{g} / 1$ (Menzel and Ryther, 1970).

Deep-sea sediments have a mean organic carbon content of 0.3 per cent, with a median value of 0.1 per cent (McIver, 1975). Hunt (1974) has shown similar values when considering the variance with lithology of deep-sea organic carbon contents. Simple addition of typical deep seawater values, e.g., 10 to $25 \mu \mathrm{g} / 1$ of total particulate matter and 5 to $10 \mu \mathrm{g} / 1$ of particulate 
organic carbon, would suggest that the resulting sediments should contain 20 to 50 per cent organic carbon. The particulate matter in deep sea water has been estimated to contain between 25 and 50 per cent organic matter (McCave, 1975). Sedimentation is a dynamic process and, hence, the long-term accumulation rate is dependent on concentrations at the "clear water" minimum. Since deep water samples are taken instantaneously (i.e., they represent the standing concentration, not taking rates of sedimentation into account), differential settling must be considered. Settling rates for organic (Riley, 1970) and inorganic particles, Table 2, show a maximum of one order of magnitude difference between experimentally determined values for organic aggregates, a non-ideal case, and maximum theoretical values for perfect spheres of quartz or calcite, vitrinite, and fusinite obtained by the application of Stokes law (Galehouse, 1971). In practice, microfossils and nannofossils would be expected to settle at a slower rate because of lower bulk densities and external protuberances. It appears from Table 2 that differential settling might increase the relative concentration of organic carbon by one order of magnitude as a maximum. After such a correction, the sediment accumulating on the sea floor would still be expected to contain at least 10 times more organic carbon (e.g., 2 to $5 \%$ ) than found in most deepsea sediments.

This rough calculation shows agreement with the organic carbon content of the near sea-floor nepheloid layer deduced from Table 1, where an average organic carbon content of $2 \mu \mathrm{g} / 1$ is associated with average particulate contents of about $100 \mu \mathrm{g} / 1$.

A discrepancy of one order of magnitude remains. It can be accounted for by two possible mechanisms: by dilution of the settling matter by bottom-transported organic-free mineral matter in a ratio of at least $10: 1$, or by a high level of bottom faunal or bacterial reworking of the accumulated sediments. Known values for sedimentation rates preclude a major contribution from the former mechanism, as well as the lack of a source for the mineral matter. Therefore, this analysis provides strong evidence for a high level of benthic or bacterial activity, which reworks the organic matter in most deep-

TABLE 2

Settling Velocities of Spheroidal Particles of $10 \mu \mathrm{m}$ Diameter

\begin{tabular}{lcc}
\hline \multicolumn{1}{c}{ Spheroidal Particles } & $\begin{array}{c}\text { Settling } \\
\text { Velocity } \\
\text { (m/sec) }\end{array}$ & $\begin{array}{c}\text { Time to Settle } \\
\text { Through } 4000 \mathrm{~m} \text { of } \\
\text { Water }(\mathrm{yr})\end{array}$ \\
\hline $\begin{array}{l}10 \mu \mathrm{m} \text { quartz or calcite } \\
\left(\text { density } 2.6 \mathrm{~g} / \mathrm{cm}^{3}\right)\end{array}$ & $62 \times 10^{-6}$ & 2.0 \\
$\begin{array}{l}10 \mu \mathrm{m} \text { fusinite } \\
\left(\text { density } 1.6 \mathrm{~g} / \mathrm{cm}^{3}\right)\end{array}$ & $23 \times 10^{-6}$ & 5.4 \\
$\begin{array}{l}10 \mu \mathrm{m} \text { vitrinite } \\
\left(\text { density }=1.3 \mathrm{~g} / \mathrm{cm}^{3}\right)\end{array}$ & $12 \times 10^{-6}$ & 10.9 \\
$\begin{array}{l}5 \text { to } 15 \mu \mathrm{m} \text { organic } \\
\text { aggregates }\end{array}$ & 3 to $6 \times 10^{-6}$ & 22.0 \\
\hline
\end{tabular}

${ }^{\mathrm{a} C}$ alculated from Stokes law.

${ }^{b}$ Experimental values (Riley, 1970). sea sediments. The broad geographic base of the data in Table 1 suggests that extensive organic activity is the norm in bottom sediments of all the major oceans.

It follows that, as in shallower water, preferential removal of the more biodegradable organic matter is to be expected. The faster settling rates for higher density particles will increase their relative abundance in the sediments. Organic matter attached to or absorbed on inorganic particles will also experience accelerated settling and, hence, be enriched. Evidence for incorporation of dissolved organic matter in sediments based on carbon isotopes has been proposed (Gormly and Sackett, 1977). Perturbation of the system could occur by exchange between particulate and dissolved organic carbon. In deep waters, about 30 times more organic matter exists in solution than in the particulate form (Menzel and Ryther, 1970). Bacteria have been shown to produce particulate from dissolved organic carbon (Parsons and Seki, 1970).

\section{A CONCENSUS OF RESULTS}

The sediments of Site 397 can be subdivided using the previously defined sedimentological units (Site Report, this volume). The relationships of these units to the shipboard organic geochemical studies are discussed in the organic geochemistry section of the Site Report (this volume). Briefly, these units are as follows:

Unit 1: 0 to 300 meters, Quaternary to Pliocene in age. Fluctuating organic-rich and organic-poor siliceous and carbonate oozes.

Units 2 and 3: 300 to 690 meters, Pliocene to late Miocene in age. Organic-lean hemipelagic oozes and chalks.

Unit 4: 690 to 1300 meters Miocene in age. Allochthonous slumped and turbiditic clays, silts, and sands, with high organic carbon values in the finer units. Sediments of Units 2 and 3 type continue as a minor component (background sedimentation, Facies $F_{5}$ ) interspersed with the allochthonous sediments of Unit 4.

Unit 5: 1300 to 1452 meters, Hauterivian (Early Cretaceous) in age. Organic-rich silty claystones with sideritic lamellae.

\section{Maturity}

All authors described the entire section as immature that is. in an early stage of organic genesis. Their maturation data, from techniques as diverse as the temperature of maximum volatile evolution during pyrolysis (Deroo et al., this volume), vitrinite reflectance (Cornford et al.; Pearson et al.; Kendrick et al., all this volume), thermal alteration index (Johnson et al., this volume), and extract quantity and type, are in reasonable agreement with the measured down-hole temperatures, which extrapolate to about $65^{\circ} \mathrm{C}$ at 1500 meters. If time and temperature are considered, a high sedimentation rate ( $\sim 80 \mathrm{~m} / \mathrm{m} . \mathrm{y}$.) in the upper part of the hole, would indicate that the duration of heating (effective heating time) is short. For example, the Cretaceous sediments at 1450 meters have been subjected to temperatures over the $10^{\circ} \mathrm{C}$ interval from 55 to $65^{\circ} \mathrm{C}$ for 
only 3 million years. This short effective heating time would be predicted to give a lower maturation stage for a given temperature.

\section{Type of Organic Matter}

To extract useful paleogeographic information from the reports cited earlier, it is necessary to compare the vocabularies used by the various authors to describe the organic matter. Table 3 contains a list of approximate equivalents, the terms being taken mainly from the tabulated results. In the left-hand column, these are related to the origin (provenance) of the organic matter (a genetic classification), while the petroleum potential is indicated in the right-hand column.

The samples studied are listed in Table 4 and related to the lithostratigraphic units and lithofacies described in the Site Report (this volume). Also given for comparison are the organic carbon and extract yields determined by the various authors. While the variability in organic carbon (a well-standardized procedure) is probably due to sediment inhomogeneity (e.g., see Erdman and Schorno, 1976), the variation in extract quantities must also be related to the extraction method and the solvent used. On the basis of organic carbon content, the Organic Geochemical Panel (OGP) samples from Sections 397-95-4, 397A-12-2, and 397A-16-4 are heterogeneous, which is expected for the slump sediments of Lithofacies F4a (Site Report, this volume). Sections 397A-23-4 (Lithofacies F3) and 397A-51-4 (Cretaceous) show little variability in organic carbon values, and are presumably homogeneous.

The results obtained by the various authors concerning the type of organic matter encountered at Site 397 are tabulated in Table 5 . These results can be related to the source of the organic matter via Table 3. Each lithostratigraphic unit is considered in turn.

\section{Unit 1: 0 to 300 Meters (mean organic carbon of $0.45 \%$; Site Report, this volume)}

This unit is described by Johnson et al. (this volume) as containing a predominantly woody and coaly kerogen with perhaps some indication of reworking; by Cornford et al. and Kendrick et al. (this volume) as containing a predominantly higher plant suite of particles such as vitrinite, inertinite and spores, pollen, and cuticle of the liptinite group. They also report a minor content of amorphous or algal fluorescing debris.

Erdman et al. (this volume) report heavy (marine) carbon isotope values for the lipids. Nevertheless, the

TABLE 3

Comparison of Terms ${ }^{\mathrm{a}}$ Used to Describe Kerogen and Their Use as Indicators of Sediment Provenance and Petroleum Potential, DSDP Site 397

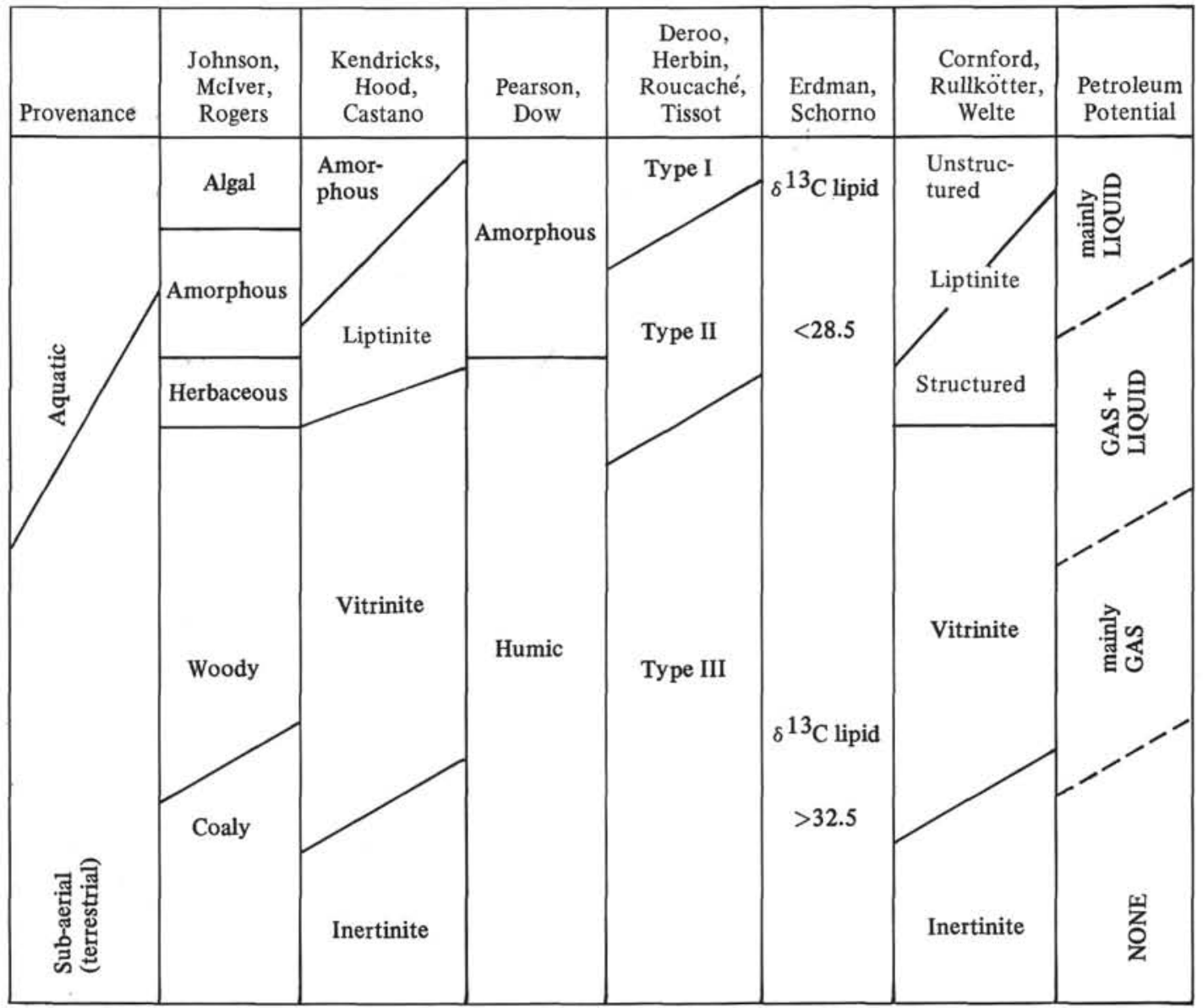

${ }^{\text {a }}$ Terms taken mainly from tables of results of the various authors (this volume). 
TABLE 4

Lithologies of DSDP Site 397 Samples for Organic Geochemical Analysis and Comparison of Organic Carbon Content and Extract Yield of the Various Authors (this volume)

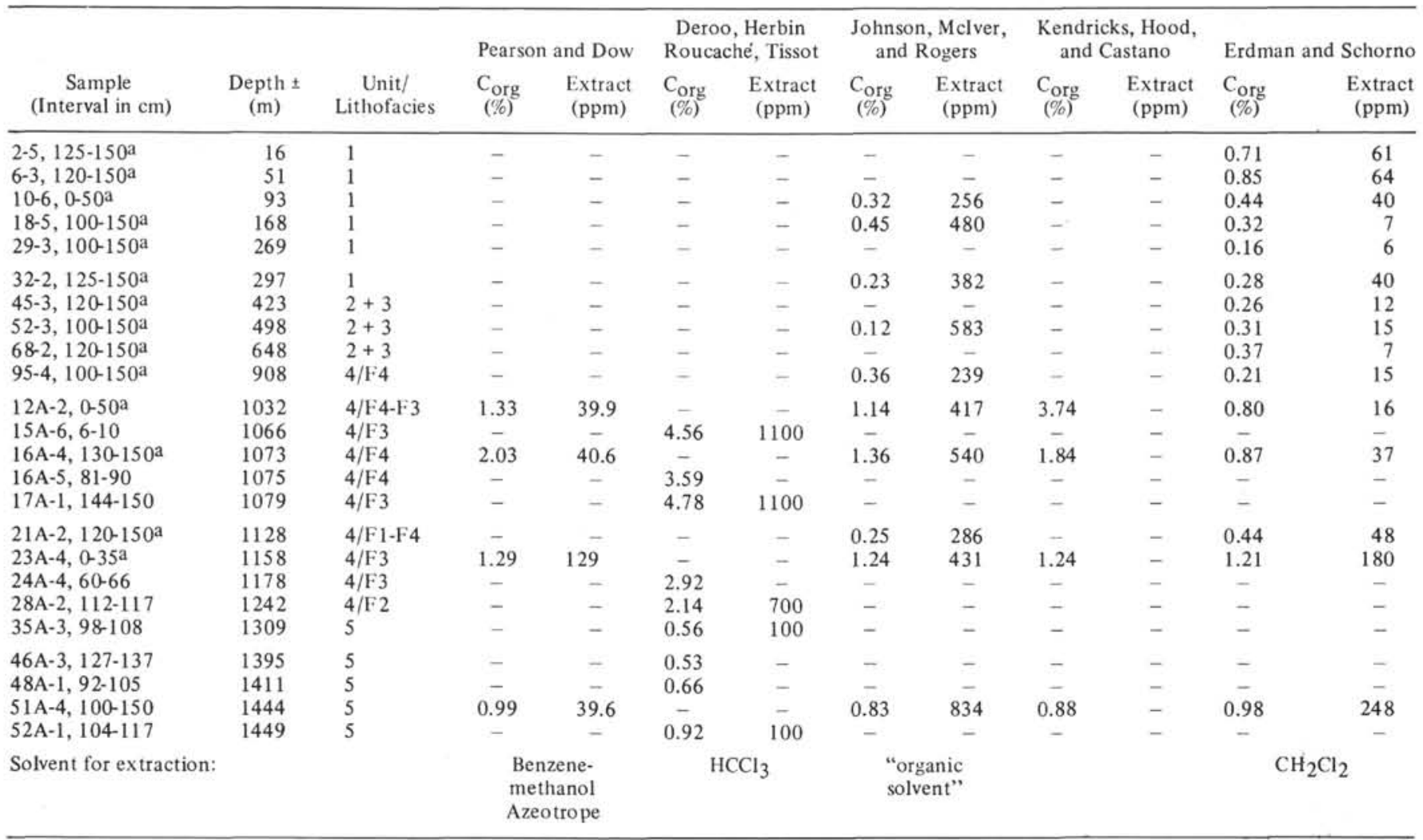

aOrganic Geochemistry Panel Sample.

TABLE 5

Classification of Organic Matter as to Source for the Various Lithologic Units, DSDP Site 397

\begin{tabular}{|c|c|c|c|c|c|c|c|c|}
\hline \multirow[b]{4}{*}{ Authors } & \multirow[b]{4}{*}{ Maturity } & \multicolumn{6}{|c|}{ Organic Matter (Kerogen) Type } & \multirow[b]{4}{*}{ Unit 5} \\
\hline & & \multirow[b]{3}{*}{ Unit $1^{\mathrm{a}}$} & \multirow{3}{*}{$\begin{array}{c}\text { Unit } 2 \\
+ \\
\text { Unit } 3\end{array}$} & \multicolumn{4}{|c|}{ Unit 4} & \\
\hline & & & & \multicolumn{4}{|c|}{ Lithofacies } & \\
\hline & & & & 2 & 3 & $4 a$ & $4 b+1$ & \\
\hline $\begin{array}{l}\text { Pearson, } \\
\text { Dow }\end{array}$ & Immature & - & $\begin{array}{l}\text { amorph.+ } \\
\text { secondary } \\
\text { humic }\end{array}$ & - & \multicolumn{2}{|c|}{ amorphous } & - & humic \\
\hline $\begin{array}{l}\text { Deroo, } \\
\text { Herbin, } \\
\text { Roucaché, } \\
\text { Tissot }\end{array}$ & Immature & - & - & - & \multicolumn{2}{|c|}{ Type II } & - & Type III \\
\hline $\begin{array}{l}\text { Johnson, } \\
\text { McIver, } \\
\text { Rogers }\end{array}$ & Immature & $\begin{array}{l}\text { woody } \\
+ \\
\text { coaly }\end{array}$ & $\begin{array}{l}\text { woody } \\
+ \\
\text { coaly }\end{array}$ & - & $\begin{array}{l}\text { algal+ } \\
\text { woody }+ \\
\text { herbaceous }\end{array}$ & $\begin{array}{c}\text { woody } \\
+ \\
\text { algal }\end{array}$ & - & $\begin{array}{l}\text { woody } \\
+ \\
\text { herbaceous }\end{array}$ \\
\hline $\begin{array}{l}\text { Kendricks, } \\
\text { Hood, } \\
\text { Castaño }\end{array}$ & Immature & vitrinitic & - & - & terrestrial & amorphous & - & vitrinitic \\
\hline $\begin{array}{l}\text { Cornford, } \\
\text { Rullkötter, } \\
\text { Welte }\end{array}$ & Immature & $\begin{array}{l}\text { higher } \\
\text { plant }\end{array}$ & $\begin{array}{l}\text { higher plant } \\
+ \text { minor } \\
\text { algal matter }\end{array}$ & $\begin{array}{l}\text { higher } \\
\text { plant }\end{array}$ & $\begin{array}{l}\text { higher } \\
\text { plant }\end{array}$ & $\begin{array}{l}\text { algal+ } \\
\text { higher } \\
\text { plant }\end{array}$ & barren & $\begin{array}{l}\text { higher } \\
\text { plant }\end{array}$ \\
\hline
\end{tabular}

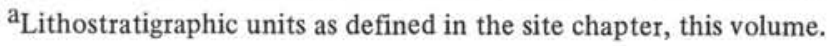


chromatogram of the $n$-heptane soluble lipids shows an $n$-alkane distribution maximizing in the $\mathrm{C}_{27}$ to $\mathrm{C}_{29}$ region with a large odd chain length predominance. This distribution is consistent with derivation from land plant waxes. Thus, most of the evidence from the few cores investigated in this unit suggests that the sediments contain moderate amounts of organic matter of terrestrial origin.

\section{Units 2 and 3: 300 to 690 Meters (mean organic carbon of $0.17 \%$; Site Report, this volume)}

Sediments from these units are lean in organic material. They are described by Johnson et al. (this volume) as woody and coaly, while Erdman et al. (this volume) report lipid $\delta^{13} \mathrm{C}$ values in the marine to intermediate range and show chromatograms of the $n$-heptane soluble lipids with maxima in the $\mathrm{C}_{27}-\mathrm{C}_{31}$ and $\mathrm{C}_{19}$ ranges, the former predominating. Cornford et al. (this volume) found these units to contain vitrinite, little inertinite, but considerable fluorescent (liptinitic) matter which was a mixture of higher plant (pollen, cuticle) and amorphous, filamentous, and unicellular algal particles.

This interval contains a mixed type of organic matter with a predominant contribution from terrestrial higher plants, but some evidence of minor input from planktonic sources.

\section{Unit 4: 690 to 1300 Meters (mean organic carbon of} $1.39 \%$; Site Report, this volume)

Unit 4 consists of five major lithofacies (Site Report sedimentology section); three were investigated by organic geochemists. These lithofacies can be grouped in the following way:

1) Lithofacies F2 and F3; green, well-sorted sometimes graded silts and clays of turbiditic origin.

2) Lithofacies F4a; a poorly-sorted coarse shell "hash" probably emplaced by a mass slumping mechanism.

3) Lithofacies F4b and F1; coarse-grained beds of volcanoclastic and quartz sand composition, respectively.

Since OGP sections are not lithologically described by the shipboard party, the lithofacies designation of these samples can only be inferred by interpolation between the lithologies above and below. The inferred lithotypes of the OGP sections and those known for Deroo et al. (this volume) are given in Table 2. Those of Cornford et al. are given in their report (this volume).

Considerable variation exists in the descriptions of the type of organic matter found in this unit, and this variation is not obviated by comparing only data from a single lithofacies. Cornford et al. (this volume), on evidence from microscopy, concluded that Lithofacies F2 and F3 contain a predominance of higher plant matter, while Lithofacies F4a has a higher amorphous or algal input, a result that is confirmed by the study of Kendrick et al. (this volume). In contrast, Pearson et al. and Deroo et al. (this volume) found the sediments of Lithofacies F2, F3, and F4 to be similar and to contain a predominantly amorphous or Type II marine al- gal organic matter (see Table 3), while Johnson et al. (this volume) report a mixed algal and higher plant kerogen, but with the Lithofacies F3 sample being the most algal rich. This latter conclusion is supported by the $\delta^{13} \mathrm{C}$ analysis of Erdman et al. (this volume), who find the lipid fractions of the Lithofacies F3 sample to be isotopically heaviest (most marine), while some of the Lithofacies F4a samples give the lightest values in the hole.

From analysis of the $n$-alkane distributions reported for this unit, Deroo et al. (this volume) show a markedly terrestrial distribution for F3 samples and an algal distribution for F2 samples. Cornford et al. (this volume) show bimodal $n$-alkane distributions for F3 samples indicating both algal and higher plant wax contributions, and F2 sample in which $n$-alkanes were only minor components and with a high percentage of steranes, sterenes, and triterpane.

Little can be concluded from these results other than that there appears to be inhomogeneity within the sediments, discrepancies between the laboratories, and also between the results from different techniques applied to a single sample within the same laboratory. Reasons for these discrepancies are discussed in the next section. It can be concluded that the unit contains at least some terrestrial and marine organic input, probably inhomogeneously distributed, but that no consistent trend can be seen from the fine-grained Lithofacies F3 to the coarse-grained suspended flow matter of F4a. Placing greater emphasis on representative techniques such as pyrolysis (Deroo et al., this volume), and a consensus of the microscopy results (Table 3 ), this unit contains more marine derived organic matter than others at Site 397.

\section{Unit 5: 1300 to 1452 Meters (mean organic carbon of $0.56 \%$; Site Report, this volume)}

There is unanimity concerning the type of the organic matter in Unit 5. All authors agree that the Lower Cretaceous contains a kerogen of terrestrial plant derivation. Typical plant wax $n$-alkane distributions (Cornford et al., Pearson et al., both this volume), woody or coaly kerogens, and $\mathrm{H} / \mathrm{C}$ and $\mathrm{O} / \mathrm{C}$ values attest to the terrestrial origin of these sediments. Deroo et al. and Cornford et al. (both this volume) also invoke the possiblity of recycling or distal transport for part of the terrestrial component. Results from other DSDP holes in the Atlantic show that land-derived organic matter is common in Cretaceous sediments.

\section{SYNTHESIS}

\section{Maturity}

The organic maturity at Site 397 , determined by diverse techniques, is low and in agreement with the relatively shallow penetration. Downhole temperature measurements predict a gradient of $42^{\circ} \mathrm{C} / \mathrm{km}$. This relatively high gradient, which gives vitrinite reflectance values of 0.45 at about 1500 meters (Pearson et al.; Cornford et al., both this volume) may be due to the volcanic activity of the nearby Canary Island volcanic cen- 
ter. If true, and given that the earliest volcanic episode of the Canaries at this site is of a Miocene age, it is not reasonable to assume that the present-day geothermal gradient existed during the Cretaceous.

Thus, the discrepancies between the interpretations of Pearson et al. and Cornford et al. (both this volume), concerning the thickness of sediment lost in the Lower Cretaceous-Miocene unconformity, become academic. The differences in result $(360$ versus $<1300 \mathrm{~m})$ stem from differences in interpretation. Pearson et al. believe that excavated and reburied vitrinite starts to increase in reflectance (though at a lower rate than first-generation material) as soon as reburial starts; Cornford et al. believe that the vitrinite must be reburied to approximately its original depth before the reflectance increases significantly. Discussion of the paleogradient in the Cretaceous must be speculative. Values of 20 to $25^{\circ} \mathrm{C} /$ $\mathrm{km}$ are more typical of the present-day passive margins, but during early opening of an ocean, higher values might be expected.

\section{Organic Facies}

\section{Unit 1: 0 to 300 Meters}

Fluctuating high and low organic carbon values in this interval could be due to at least two processes. The first is a fluctuating terrestrial organic input, perhaps relating to the series of glacial/interflacial episodes, as suggested by Diester-Haass (this volume). The second process is the high productivity (and preservation) of marine planktonic organisms due to the development of deep water upwelling in the Pliocene-Pleistocene.

While the high biogenic content in Unit 1 sediments, along with the rapid sedimentation rates (Site Report, this volume), suggest the process of high planktonic bioproductivity, the fact that the organic matter in this unit is predominantly of terrestrial origin indicates a low survival rate of the organic matter of the planktonic biomass. Summerhayes et al. (1976) have shown that little organic matter survives to be incorporated in recent sediments deposited beneath areas of upwelling off southeastern Brazil.

The terrigenous input to these sediments is semiquantitatively demonstrated from the smear slide analysis, which indicates an average input of about 25 per cent of terrigenous components (Site Report, this volume). Thus, although the majority of the sedimentary particles are biogenic, the survival and preservation of the organic matter favors the terrestrial component.

As discussed previously, differential settling will initiate this enrichment, while the present-day conditions of nutrient-rich and oxygen-rich waters at depth, will favor destruction by the benthic population of the easily degradable planktonic matter, while allowing the more resistant terrestrial matter to survive.

\section{Units 2 and 3: 300 to 690 Meters}

The organic content of this unit is low but that matter which is present is dominated again by terrestrial particles. These hemipelagic sediments contain a high fraction of biogenic mineral matter, so it appears again that in this deep water continental rise setting, the al- lochthonous terrestrial organic matter has a better survival rate than the autochthonous planktonic input.

\section{Unit 4: 690 to 1300 Meters}

This unit is atypical of Miocene deep-sea sediments of the Atlantic, both in its high organic carbon content and its violent mode of deposition. Organic-rich Miocene sediments were encountered during Leg 38, on the V $\phi$ ring Plateau (Erdman and Schorno, 1976). From the organic geochemistry reports, the type of organic matter present at Site 397 seems highly variable. Accepting analytical and interpretational difficulties, the kerogen type appears to fluctuate from algal-rich to predominantly terrestrial matter. This is not an unreasonable conclusion since these sediments contain allochthonous benthic and planktonic foraminiferal assemblages, which appear to have originated in an outer shelf environment (Site Report, this volume). The organic matter in these sediments, therefore, could be derived from a variety of depositional environments.

Preservation of large quantities of organic matter is typical of anoxic environments, which suggests that these sediments have been transported from a position where the oxygen minimum encroaches on outer shelf sediments (Figure 1). Subsequent rapid transport and deposition by slumping or turbid flow has brought them to their present position. Thus, the deposition of these anomalous organic-rich Miocene deep-sea sediments appears to be due to a combination of: (1) oxygen-minimum conditions on the shelf edge providing a mechanism for the preservation of significant autochthonous marine as well as allochthonous terrestrial organic matter, and (2) sediment flow allowing emplacement in the deep sea.

\section{Unit 5: 1300 to 1452 Meters}

This unit is composed of Lower Cretaceous cyclic claystone and siderite sediments with terrestrial organic content, which were deposited during the early spreading stage of the central Atlantic. The sparse sedimentary evidence suggests deposition in a distal turbidite or prodelta setting (Site Report, this volume). The presence of a terrestrial kerogen and woody fragments are in agreement.

\section{CONCLUSIONS}

It is unusual for so wide a variety of organic geochemical techniques to be applied to a single set of samples. In this case, the data are sometimes in good agreement (e.g., Unit 5 ), but can also show a bewildering diversity of interpretation (e.g., Unit 4). These inconsistencies highlight the need to clarify and develop the interpretation of organic geochemical data. DSDP samples provide a unique opportunity to compare methods and interrelate interpretations.

From the literature and the organic geochemical reports of Site 397, the following conclusions can be drawn.

1) Comparison of the concentrations of particulate organic and inorganic matter in the oceans with deepsea sediments indicates considerable biodegration of organic matter at or immediately below the sea floor. 


\section{CORNFORD}

2) Hemipelagic continental rise sediments contain a dominance of land-derived organic matter, despite a dominantly planktonic input to the inorganic component of the sediment. Less refractory planktonic organic matter recycled in the upper 400 meters of water is reduced in concentration by differential settling, and is biodegraded by benthic organisms. All three mechanisms serve to enrich the more resistant terrestrial organic components.

3) Slumping and turbidity current sediment transport from the shelf-edge zone of low oxygen and high organic accumulation is a mechanism for the introduction of organic-rich sediments into deep-sea (rise) locations. This mechanism is observed for the allochthonous Miocene sediments of Unit 4, which show the highest content of marine organic matter of any of the five units.

4) The sediments show a low level of organic diagenesis.

\section{ACKNOWLEDGMENTS}

During preparation this synthesis has been circulated to all organic geochemical contributors to the Site 397 Report. I should like to thank Drs. B. Tissot, J. Kendrick, S. Palmer, D. Pearson, and K. Schorno for detailed comments and review of the manuscript. I am solely responsible for the final text.

\section{REFERENCES}

Biscaye, P. E. and Eittreim, S. L., 1977. Suspended particulate loads and transport in the nepheloid layer of the abyssal Atlantic Ocean, Marine Geology, v. 23, p. 155.

Brewer, P. G., Spencer, D. W., Biscaye, P. E., Hanley, A., Sachs, P. L., Smith, C. L., Kadar, S., and Fredericks, J., 1976. Distribution of particulate matter in the Atlantic Ocean, Earth and Planetary Science Letters, v. 32, p. 393.

Erdmann, J. G. and Schorno, K. S., 1976. Geochemistry of carbon, DSDP Leg 38. In Talwani, M., Udintsev, G., et al., Initial Reports of the Deep Sea Drilling Project, v. 38: Washington (U.S. Government Printing Office), p. 791.

Gadel, F. and Ragot, J. P., 1974. Sur l'allochtonie de la fraction organique particulaire des depots quaternaire recents du Golfe du Lion. In Tissot, B. and Bienner, F. (Eds.), Advances in organic geochemistry: Paris (Editions Technip), p. 619.

Galehouse, J. S., 1971. Sedimentation analysis, In Carver, R. E. (Ed.), Procedures in sedimentary petrology: New York (Wiley-Interscience), p. 69.

Gardner, W. S. and Menzel, D. W., 1974. Phenolic aldehydes as indicators of terrestrially derived organic matter in the sea, Geochim. Cosmochim. Acta, v. 38, p. 813.

Gordon, D. C., 1977. Variability of particulate organic carbon and nitrogen along the Halifax-Bermuda section, Deep-Sea Research, v. 24, p. 257.

Gormly, J. R. and Sackett, W. M., 1977. Carbon isotope evidence for the maturation of marine lipids. In Campos, R. and Goni, J. (Eds.), Advances in organic geochemistry: Madrid (Enadimsa), p. 321
Hunt, J., 1974. Organic geochemistry of the marine environment. In Tissot, B. and Bienner, F. Advances in organic geochemistry: Paris (Editions Technip), p. 593.

Huntsman, S. A. and Barber, R. T., 1977. Primary production off northwest Africa: The relationship to wind and nutrient conditions, Deep-Sea Research, v. 24, p. 25.

Jacobi, R. D., 1976. Sediment slides on the northwest continental margin of Africa, Marine Geology, v. 22, p. 157.

Karl, D. M., LaRock, P. A., and Shultz, D. J., 1977. Adenosine triphosphate and organic carbon in the Cariaco Trench, Deep-Sea Research, v. 24, p. 105.

McCave, I. N., 1975. Vertical flux of particles in the ocean, Deep-Sea Research, v. 22, p. 491.

McIver, R., 1975. Hydrocarbon occurrences from JOIDES Deep Sea Drilling Project, World Petroleum Congress, Tokyo, Panel Discussion v. 1, p. 1.

McMaster, R. L., Betzer, P. R., Carder, K. L., Miller, L., and Eggiman, D. W., 1977. Suspended particle mineralogy and transport in water masses of the west African Shelf adjacent to Sierra Leone and Liberia, Deep-Sea Research, v. 24 , p. 651 .

Meinhold, R., 1977. Neue Erkenntnisse über die Diagenese disperser organischer Gesteinssubstanzen, Zeitschrift für angewandte Geologie, v. 23, p. 9.

Menzel, D. W. and Ryther, J. H., 1970. Distribution and cycling of organic matter in the oceans. In Hood, D. W. (Ed.), Organic matter in natural waters, University of Alaska, p. 31.

Menzel, D. W., 1974. Primary productivity, dissolved and particulate organic matter and the sites of oxidation of organic matter. In Goldbert, E. (Ed.), The sea: New York (Intersience), v. 1, p. 659.

Milliman, J. D., 1977. Effect of arid climate and upwelling upon the sedimentary regime off southern Spanish Sahara, Deep-Sea Research, v. 24, p. 95.

Parsons, T. R. and Seki, H., 1970. Importance and general implications of organic matter in aquatic environments. In Hood, D. W. (Ed.), Organic matter in natural waters: University of Alaska, p. 1.

Richards, F. A., 1970. The enhanced preservation of organic matter in anoxic marine environments. In Hood, D. W. (Ed.), Organic matter in natural waters: University of Alaska, p. 399.

Riley, G. A., 1970. Particulate organic matter in sea water, Advances in Marine Biology, v. 8, p. 1.

Ryan, W. B. F. and Cita, M. B., 1977. Ignorance concerning episodes of ocean-wide stagnation, Marine Geology, v. 23, p. 197.

Schlanger, S. O. and Jenkins, H. C., 1976. Cretaceous oceanic anoxic events: Causes and consequences, Geologie en Mijnbouw, v. 55, p. 179.

Simoneit, B. R. T. and Eglinton, G., 1977. Organic matter of eolian dust and its input to marine sediments. In Capos, R. and Goni. J. (Eds.), Advances in organic geochemistry: Madrid (Enadımsa), p. 415.

Summerhayes, C. P., de Melo, U., and Barretto, H. T., 1976. The influence of upwelling on suspended matter and shelf sediments off south eastern Brazil, J. Sed. Petrol., v. 46, p. 819. 